\title{
CHRONIC ULCERATIVE COLITIS IN CHILDHOOD
}

\author{
A FOLLOW-UP STUDY
}

\author{
BY \\ RONALD C. KING,* ARTHUR E. LINDNER and H. MARVIN POLLARD \\ From the Department of Internal Medicine, Gastroenterology Unit, University of Michigan Medical School, \\ Ann Arbor, Michigan
}

(RECEIVED FOR PUBLICATION OCTOBER 28, 1958)

Although chronic ulcerative colitis may well have been known to Sydenham (1848), it was only comparatively recently that Helmholz (1923) first recorded the occurrence of the condition in children with an account of five cases. Since that time the disease has become increasingly recognized as a condition of childhood and larger series have been reported from America (Jackman, Bargen and Helmholz, 1940; Bargen and Kennedy, 1955; Holowach and Thurston, 1956; Meeker and Goff, 1956), from Australia (Covernton, 1949), from Sweden (Lagercrantz, 1955), and more recently from England (Schlesinger and Platt, 1958). Jackman et al. (1940) found, as a result of follow-up studies, that over half of their 95 children had either become worse or had died, whereas a more recent investigation concerning 126 children (Bargen and Kennedy, 1955) revealed a much more optimistic prognosis.

Between July 1, 1947, and June 30, 1956, a total of 391 patients attended the University Hospital with chronic ulcerative colitis. Of these $52(13 \cdot 3 \%)$ were aged 15 years or less when the disease first appeared. In an attempt to assess the prognosis of the condition as seen in childhood at this large medical centre, a follow-up study was initiated, the results of which form the basis for this communication.

The medical records of the 52 patients were studied and cases were included only if the clinical story of chronic diarrhoea was supported by negative bacteriological findings and positive radiological or sigmoidoscopic evidence. Six of the patients had been seen as out-patients but the remainder had all been investigated or treated in hospital. Simple questionnaires were then prepared and despatched and satisfactory information was

* In receipt of a Clinical Fellowship of the American Cancer Society.

Present address: St. Bartholomew's Hospital, London. obtained in 51 instances, a follow-up rate of $98.1 \%$. When surgery had been performed or death had occurred in other hospitals these were written to and the relevant surgical or autopsy details obtained.

Clinical Details. Thirty-one $(59.6 \%)$ of the patients were male and $21(40 \cdot 4 \%)$ female. Details of age distribution and duration of the disease are shown in Tables 1 and 2. The period of follow-up

TABLE 1

DETAILS OF AGE AT ONSET, AGE AT WHICH FIRST SEEN AT UNIVERSITY HOSPITAL, AND AGE AT TERMINATION OF FOLLOW-UP

\begin{tabular}{|c|c|c|c|c|c|}
\hline $\begin{array}{c}\text { Age at } \\
\text { Onset of } \\
\text { Disease } \\
(y r .)\end{array}$ & $\begin{array}{c}\text { Patients } \\
\text { (No.) }\end{array}$ & $\begin{array}{c}\text { Age when } \\
\text { First Seen } \\
\text { at University } \\
\text { I-Iospital } \\
\text { (yr.) }\end{array}$ & $\begin{array}{c}\text { Patients } \\
\text { (No.) }\end{array}$ & $\begin{array}{c}\text { Age at End } \\
\text { of Follow- } \\
\text { up* } \\
\text { (yr.) }\end{array}$ & $\begin{array}{l}\text { Patients } \\
\text { (No.) }\end{array}$ \\
\hline \multirow[t]{2}{*}{$\begin{array}{r}1 \\
2 \\
3 \\
4 \\
5 \\
6 \\
7 \\
8 \\
9 \\
10 \\
11 \\
12 \\
13 \\
14 \\
15\end{array}$} & $\begin{array}{r}- \\
- \\
-1 \\
-1 \\
1 \\
1 \\
4 \\
2 \\
3 \\
13 \\
8 \\
11 \\
8\end{array}$ & $\begin{array}{l}10 \\
11 \\
12 \\
13 \\
14 \\
15 \\
16 \\
17 \\
18 \\
19 \\
20 \\
22 \\
23 \\
24 \\
25 \\
28 \\
33\end{array}$ & $\begin{array}{r}2 \\
1 \\
4 \\
12 \\
8 \\
8 \\
2 \\
2 \\
2 \\
3 \\
1 \\
1 \\
1 \\
2 \\
1 \\
1 \\
1\end{array}$ & $\begin{array}{l}15 \\
16 \\
17 \\
18 \\
19 \\
20 \\
21 \\
22 \\
23 \\
24 \\
25 \\
26 \\
27 \\
30 \\
31 \\
34 \\
39\end{array}$ & $\begin{array}{l}5 \\
2 \\
2 \\
4 \\
3 \\
5 \\
1 \\
2 \\
2 \\
3 \\
2 \\
1 \\
3 \\
1 \\
2 \\
2 \\
2\end{array}$ \\
\hline & 52 & & 52 & & 42 \\
\hline
\end{tabular}

* Excluding nine deaths and one untraced patient.

ranged from one to 26 years, with an average of nine years. The extent of radiological involvement and the sigmoidoscopic appearances are summarized in Table 3 . The most constant radiographic finding was loss of the normal haustral markings, and this involved the entire colon in 30 $(57 \cdot 7 \%)$ of the cases. Terminal ileal involvement 
TABLE 2

DURATION (IN YEARS) OF DISEASE WHEN FIRST SEEN AND TOTAL DURATION TO DEATH, SURGERY, OR TERMINATION OF FOLLOW-UP

\begin{tabular}{|c|c|c|c|}
\hline $\begin{array}{c}\text { Duration when } \\
\text { First Seen } \\
\text { (yr.) }\end{array}$ & $\begin{array}{l}\text { Patients } \\
\text { (no.) }\end{array}$ & Total Duration & $\begin{array}{l}\text { Patients } \\
\text { (no.) }\end{array}$ \\
\hline \multirow[t]{2}{*}{$\begin{array}{r}\text { Less than } 1 \\
1 \\
2 \\
3 \\
4 \\
5 \\
7 \\
9 \\
10 \\
14 \\
15 \\
17\end{array}$} & $\begin{array}{r}15 \\
10 \\
8 \\
3 \\
5 \\
2 \\
1 \\
1 \\
3 \\
1 \\
1 \\
2\end{array}$ & $\begin{array}{r}1 \\
2 \\
3 \\
4 \\
5 \\
6 \\
7 \\
8 \\
9 \\
10 \\
11 \\
12 \\
13 \\
15 \\
16 \\
17 \\
19 \\
21 \\
23 \\
26\end{array}$ & $\begin{array}{l}1 \\
4 \\
5 \\
4 \\
3 \\
3 \\
4 \\
3 \\
3 \\
2 \\
3 \\
4 \\
2 \\
1 \\
3 \\
1 \\
2 \\
1 \\
1 \\
1\end{array}$ \\
\hline & 52 & & 51 \\
\hline
\end{tabular}

TABLE 3

EXTENT OF RADIOLOGICAL INVOLVEMENT AND SIGMOIDOSCOPIC APPEARANCES

\begin{tabular}{|c|c|c|c|}
\hline Barium Enema & $\begin{array}{l}\text { Patients } \\
\text { (no.) }\end{array}$ & Sigmoidoscopy & $\begin{array}{c}\text { Patients } \\
\text { (no.) }\end{array}$ \\
\hline \multirow[t]{2}{*}{$\begin{array}{l}\text { Not done (N.D.) } \\
\text { Normal (N.) } \\
\text { Distal (D.) } \\
\text { Left side (L.) } \\
\text { Right side (R.) } \\
\text { Total (T.) } \\
\text { Total + terminal } \\
\text { ileum (T.I.) }\end{array}$} & $\begin{array}{r}3 \\
7 \\
6 \\
5 \\
1 \\
18\end{array}$ & $\begin{array}{cc}\text { N.D. } \\
\text { Grade } & 1 \\
\text { Grade } & 2 \\
\text { Grade } & 3 \\
\text { Grade } & 4\end{array}$ & $\begin{array}{r}2 \\
1 \\
3 \\
36 \\
10\end{array}$ \\
\hline & 52 & & 52 \\
\hline
\end{tabular}

(Grade 1: oedema. Grade 2: granularity. Grade 3: granularity + bleeding. Grade 4: Grade 3 +ulceration.) was evident in $12(23 \%)$. Patients in whom barium enema was normal or in whom this investigation had not been performed all had diagnostic appearances on sigmoidoscopy, while $46(88.5 \%)$ of the children had incontrovertible sigmoidoscopic evidence of chronic ulcerative colitis. Seven (13.5\%) showed pseudo polyp formation and a stricture was found in one case. Forty-one $(79 \%)$ of the children had haemoglobin levels below $13 \mathrm{~g}$. \% (Haldane) while $11(21 \%)$ had levels below $10 \mathrm{~g} . \%$.

Results of Follow-up. Fifty-one of the 52 patients $(98 \cdot 1 \%)$ were satisfactorily followed up and of these nine $(17 \cdot 6 \%)$ were dead. Eight of the deaths $(15.7 \%)$ occurred directly or indirectly as a result of the ulcerative colitis (Table 4), while the ninth was due to portal cirrhosis, probably unrelated to mild ulcerative colitis. Carcinoma of the colon developed in four cases $(7 \cdot 8 \%)$ all of whom had had the disease for nine years or more (Table 4). Twelve of the patients $(23.5 \%)$ underwent excisional surgery with one post-operative death. This youth had severe colitis of four years' standing and in addition to a colectomy had also had duodeno-colic and jejuno-colic fistulae excised. In the remainder operations were performed as follows: ileostomy and total colectomy (5); ileostomy, total colectomy and abdomino-perineal resection of the rectum (4); sub-total colectomy with ileo-sigmoid anastomosis (2). Two patients underwent surgery for isolated fistulae (one ileal, one rectal) while six others were operated on for unrelated conditions. The surviving group of 42 patients was therefore divided into 11 who had undergone excisional surgery and 31 who had not.

Perusal of the completed questionnaires enabled a

TABLE 4

DETAILS OF FATAL AND NEOPLASTIC CASES

\begin{tabular}{|c|c|c|c|c|c|c|c|c|}
\hline Patient & Sex & $\begin{array}{c}\text { Age of } \\
\text { Onset } \\
\text { (yr.) }\end{array}$ & Duration & $\begin{array}{c}\text { Age of Death } \\
(y r .)\end{array}$ & Sigmoidoscopy & Barium Enema* & Cause of Death & Surgery \\
\hline $\begin{array}{l}35 \\
44 \\
46 \\
51\end{array}$ & $\begin{array}{l}\text { M. } \\
\text { M. } \\
\text { F. } \\
\text { M. } \\
\text { F. }\end{array}$ & $\begin{array}{r}9 \\
12 \\
11 \\
9\end{array}$ & $\begin{array}{l}2 \\
2 \\
1 \\
4\end{array}$ & $\begin{array}{l}11 \\
14 \\
12 \\
13 \\
\\
\\
19\end{array}$ & $\begin{array}{l}3 \\
2 \\
3 \\
3 \\
\\
3\end{array}$ & $\begin{array}{l}\text { L. } \\
\text { D.D. } \\
\text { T. } \\
\text { N.D. }\end{array}$ & $\begin{array}{c}\text { Exacerbation } \\
\text {,", } \\
\text { Post-operative }\end{array}$ & $\begin{array}{l}\text { Nil } \\
\text { ", } \\
\text { Excision of } \\
\text { colon, and } \\
\text { entero-colic } \\
\text { fistulae } \\
\text { Nil }\end{array}$ \\
\hline $\begin{array}{l}29 \\
42 \\
50 \\
33\end{array}$ & $\begin{array}{l}\text { M. } \\
\mathbf{M} . \\
\mathbf{F} . \\
\text { M. }\end{array}$ & $\begin{array}{r}12 \\
10 \\
9 \\
13\end{array}$ & $\begin{array}{r}14 \\
21 \\
15 \\
9\end{array}$ & $\begin{array}{l}26 \\
31 \\
23 \\
\text { Alive and well } \\
3 \text { years post- } \\
\text { operatively }\end{array}$ & $\begin{array}{l}3 \\
3 \\
4 \\
3\end{array}$ & $\begin{array}{l}\text { T.I. } \\
\text { T.I. } \\
\text { T.I. } \\
\text { T.I. }\end{array}$ & $\begin{array}{c}\text { Carcinoma } \\
\text { ", }\end{array}$ & $\begin{array}{l}\text { Laparotomy } \\
\text { ", } \\
\text { Cölectomy, } \\
\text { and excision } \\
\text { of carci- } \\
\text { noma }\end{array}$ \\
\hline
\end{tabular}

* Abbreviations as in Table 3 . 
detailed assessment to be made of the patients' condition at the end of the follow-up. Five $(45 \cdot 5 \%)$ of the surgical group were underweight for their height as compared with nine $(29 \%)$ of the medically treated patients. Nine $(82 \%)$ of the surgical group were working or attending school or college regularly, while $30(97 \%)$ of the medical group were similarly employed. Eight of the surgical group were aged 19 years or more at the termination of the follow-up. Of these, three $(37 \cdot 5 \%)$ were married with children, four $(50 \%)$ were unmarried, while the status of one was not known. Twenty-two of the medical group were aged 19 or more at the termination of the follow-up and of these $12(54.5 \%)$ were married, seven (32\%) with children. Nine (82\%) of the surgical group stated that their condition was excellent, one ( $9 \%$ ) with an ileo-sigmoidostomy lacked energy, while in one case insufficient time had elapsed since operation for an opinion to be given. By contrast only $17(55 \%)$ of the medical group described their condition as excellent and could be considered inactive, while $14(45 \%)$ were having persistent symptoms with more than four motions a day and the intermittent passage of blood and/or mucus. Only $2(18 \%)$ of the surgical group had required further admission to hospital (revision of ileostomy, drainage of perineal abscess) but 14 $(45 \%)$ of the medical group had been subsequently admitted to hospital on account of the colitis. Three $(27 \%)$ of the surgical group had suffered episodes of ill health not necessitating admission but $14(45 \%)$ of the medical group had been inconvenienced in this way.

\section{Discussion}

The clinical features of the cases considered here do not differ in any important respects from recently described series. The present status of chronic ulcerative colitis in childhood has been well summarized by Lyons (1956), and in our patients no new pathological or aetiological factors were discovered, neither were any new diagnostic methods employed. Treatment was along orthodox lines, with rest, diet, antispasmodics, antibiotics and steroids, with blood transfusion and psychiatric or surgical intervention when necessary.

The unpredictable and at times fulminant course of ulcerative colitis in childhood makes it difficult to relate the condition at the time of examination with the ultimate outcome. Complete involvement of the colon will usually imply a more serious state and although this has been shown to affect the prognosis adversely in adults (Cullinan and MacDougall, 1957) such is not the case in childhood (Lyons, 1956). It is true that nine $(75 \%)$ of the patients who came to surgery had total involvement when seen at the University Hospital as against 16 $(52 \%)$ of the medical group, and similarly the four patients who developed colonic neoplasms had the entire colon and also the terminal ileum affected. However, of the five patients who died during acute exacerbations of the colitis, three had radiographic examination of the colon and of these only one had total involvement. In the remaining two the distal colon only was affected. Rapid progression and spread of the condition must have occurred as both died within a few months of being seen. A symptomatic appraisal of the patients treated medically reveals a similar lack of correlation between the extent of involvement and ultimate condition. Twenty-four of the 31 patients in the medical group had abnormal colon radiographs, 16 with total and eight with distal or segmental involvement. Reference to Table 5 reveals that patients with localized

TABLE 5

RELATION OF SUBSEQUENT SYMPTOMS TO DEGREE OF INVOLVEMENT ON BARIUM ENEMA WHEN SEEN AT UNIVERSITY OF MICHIGAN HOSPITAL

\begin{tabular}{|c|c|c|c|}
\hline X-ray & $\begin{array}{c}\text { Total } \\
\text { involvement } \\
(16) \\
(\%) \\
\end{array}$ & $\begin{array}{c}\text { Segmental } \\
(8) \\
(\%)\end{array}$ & $\begin{array}{c}\text { Normal } \\
(7) \\
(\%)\end{array}$ \\
\hline $\begin{array}{l}\text { More than four motions } \\
\text { daily } \\
\text { Blood in stools } .\end{array}$ & $\begin{array}{l}31 \\
31 \\
31 \\
56 \\
31\end{array}$ & $\begin{array}{l}37 \cdot 5 \\
25 \\
50 \\
75 \\
37 \cdot 5\end{array}$ & $\begin{array}{r}0 \\
29 \\
14 \\
43 \\
43\end{array}$ \\
\hline
\end{tabular}

involvement in fact suffered more subsequent inconvenience from their colitis than those in whom the entire colon was affected, while those in whom only the sigmoidoscopy was abnormal suffered less. Of the 28 patients in the medical group with Grade 3 or 4 sigmoidoscopic changes, seven $(25 \%)$ continued to pass four or more motions a day, $10(35.7 \%)$ persistently passed blood or mucus, $17(60.7 \%)$ experienced periods of ill health, while in 11 cases $(39.3 \%)$ this had necessitated further admission to hospital.

The incidence of malignant degeneration is high $(7 \cdot 8 \%)$. Even more striking is the early age at which the neoplasms occurred, the average age at the time of death from or diagnosis of the neoplasm being $25 \cdot 25$ years. There is now little doubt that chronic ulcerative colitis is a pre-malignant condition in both adults and children. The recorded incidence of carcinoma varies, in adults, depending on whether the material is derived from medical or surgical sources. Thus in medical series Sloan, Bargen and Gage (1950) reported 109 instances of 
neoplasm in 2,000 cases, Kiefer, Eytinge and Johnson (1951), nine in 458, Weckesser and Chinn (1953), four in 118, Banks, Korelitz and Zetzel (1957), nine in 245, and Cullinan and MacDougall (1957) six in 346, whereas from surgical sources Kiefer et al. (1951) recorded 10 in 226, Lyons and Garlock (1951) nine in 226, Hurt (1954) two in 18, Bacon, Yang, Carroll, Cates, Villalba and McGregor (1956) 12 in 84, and Thorlakson (1956) 12 in 182 . The tendency for malignant change to occur increases, not unexpectedly, with the duration of the colitis, and in the series reported by Lyons and Garlock (1951) $36 \%$ of those who had had the disease longer than 12 years developed carcinomata. This susceptibility to carcinoma of the large bowel has been variously estimated as from five times (MacDougall, 1954) to 66 times (Kiefer et al., 1951) that of the normal population. The growths may have multifocal origins (Gelber, Hawthorne and Gelb, 1955) and usually progress rapidly. Fewer reports are available concerning colitis and malignancy in children, but Tidrick and Hickey (1956) recorded six cases, all of whom developed their colitis in childhood, while Meeker and Goff (1956) described one similar case. In larger series Lagercrantz (1955) reported six instances of malignant degeneration in 150 children, Bargen and Kennedy (1955) six in 139, and Schlesinger and Platt (1958) two in 60. To date only five authentic cases of neoplasm complicating ulcerative colitis during childhood have been described (Wilcox and Beattie, 1956). Four $(16.7 \%)$ of our 24 patients who had had the disease longer than nine years developed carcinomata, a figure which should weigh very heavily in favour of excisional surgery when the management of the long standing chronic disease is being considered. The case for surgery becomes even stronger when one compares the operative mortality with the risk of malignant degeneration (Hagan and Hagan, 1957).

Six $(75 \%)$ of the eight patients who died from their colitis were male. Excluding deaths from neoplasm the remainder all occurred within five years of onset, three being within two years of the first appearance of the disease. It is interesting to note that only one of these five patients underwent surgery and he only when his condition was desperately complicated by duodeno-colic and jejunocolic fistulae, and it is reasonable to suppose that some of these lives might have been saved had surgical treatment been more readily undertaken. Lyons (1956) has recently summarized the two main indications for surgery in chronic ulcerative colitis of childhood as (1) danger to life, and (2) invalidism. Under the first heading come such situations as acute fulminating toxaemia, haemorrhage, and perforation, impending or actual, while invalidism may be the result of intractability, stricture, pericolic abscess, fistulae or polyposis.

The risk of malignant degeneration in the long standing case is so real that we consider this also constitutes a very definite danger to life and provides another indication for elective surgery. The tendency now is to perform ileostomy with colectomy and rectal resection in one or two stages, although in some cases ileo-rectal anastomosis may be possible. The age at which surgery is performed will depend very much on the patient's condition, but it is interesting to note that of the six patients who underwent surgery after the age of 18 only one was underweight at the time of the termination of the follow-up, while of the five patients who were operated on before the age of 18 , four were subsequently underweight. The results of surgery in this small series were excellent in $82 \%$ and compare very favourably with the $45 \%$ of medically treated patients who were enduring chronic ill health and, of course, the risk of later malignant degeneration.

Some interesting facts relating to mortality and surgical treatment emerge when comparisons are made between the 26 cases first seen before and the 25 cases first seen after July, 1951. As regards age of onset and extent of radiological and sigmoidoscopic involvement the two groups are comparable, although those in the first group had a much longer duration of the disease. The same principles of medical treatment were applied to all patients (six in the first group and eight in the second receiving steroids) while excisional surgery was employed in seven and five cases respectively. The two striking differences are in mortality and time at which surgery was performed. Excluding deaths from carcinoma, the mortality in the first group $(15.4 \%)$ is nearly four times that of the second $(4 \%)$. Although improvements in medical treatment may be partly responsible one cannot escape the conclusion that earlier surgery also played a part in lowering the mortality. In the first group surgical treatment was employed, on average, eight years after the onset and within three years of first being seen at the University Hospital, while in the second group operation was performed, on an average, within four years of the onset and within seven months of first being seen.

Table 6 summarizes the overall results of the follow-up. A childhood condition in which $27 \cdot 4 \%$ of the sufferers continue with chronic ill health and from which $15 \cdot 7 \%$ die, constitutes a serious challenge to medical science. In the absence of any more effective conservative remedy the results of this 
TABLE 6

OVERALL RESULTS IN 51 CASES FOLLOWED UP

\begin{tabular}{|c|c|c|c|c|}
\hline & & & Number & Percentage \\
\hline $\begin{array}{l}\text { Treatment: } \\
\text { Medical }\end{array}$ & $\cdots$ & $\begin{array}{l}\text { Asymptomatic } \\
\text { Recurrent symptoms } \ldots\end{array}$ & $\begin{array}{l}17 \\
14\end{array}$ & $\begin{array}{l}33 \cdot 3 \\
27 \cdot 4\end{array}$ \\
\hline Surgical & $\cdots$ & $\begin{array}{l}\text { Asymptomatic } \\
\text { Lacking in energy } \\
\text { Too early to assess }\end{array}$ & $\begin{array}{l}9 \\
1 \\
1\end{array}$ & $\begin{array}{r}17 \cdot 6 \\
2 \cdot 0 \\
2 \cdot 0\end{array}$ \\
\hline \multirow[t]{2}{*}{ Death } & $\ldots$ & 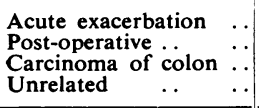 & $\begin{array}{l}4 \\
1 \\
3 \\
1\end{array}$ & $\begin{array}{l}7 \cdot 8 \\
2 \cdot 0 \\
5 \cdot 9 \\
2 \cdot 0\end{array}$ \\
\hline & & & 51 & $100 \cdot 0$ \\
\hline
\end{tabular}

investigation suggest that these figures might be improved by the more frequent use of surgery in the early acute condition and by its ultimate employment in the long standing chronic case.

\section{Summary}

Fifty-one of 52 children $(98 \cdot 1 \%)$ with chronic ulcerative colitis were successfully followed up for from one to 26 years after the onset of the disease.

Eight $(15.7 \%)$ had died as a result of the colitis, four $(7 \cdot 8 \%)$ had developed carcinoma of the colon, and $12(23 \cdot 5 \%)$ had undergone excisional surgery, with one $(2 \%)$ post-operative death.

Of the patients who had had the disease longer than nine years $16 \cdot 7 \%$ developed colonic neoplasms.

Of 31 patients managed medically $14(45 \%)$ continued with active disease, and $17(55 \%)$ appeared to be inactive, whereas nine $(82 \%)$ of the patients who survived surgery described their condition as excellent.
Analysis of the results suggests that both the morbidity and the mortality rates would be improved by the more frequent employment of surgical measures both in the early acute, and in the long standing chronic case.

We would like to express our appreciation to Mrs. Jean Waters and her staff of the University Hospital Follow-up Unit for their splendid co-operation in this study, to Dr. Robert J. Bolt for his helpful suggestions and review of this material, and to Mrs. A. Milne for secretarial assistance.

\section{REFERENCES}

Bacon, H. E., Yang, L. M. O., Carroll, P. T., Cates, B. A., Villalba, G. and McGregor, R. A. (1956). Amer. J. Surg., 92, 688.

Banks, B. M., Korelitz, B. I. and Zetzel, L. (1957). Gastroenterology, 32. 983 .

Bargen, J. A. and Kennedy, R. L. J. (1955) Postgrad. Med., 17, 127.

Covernton, J. (1949). Clin. Rep. Adelaide Child. Hosp., 1, 230.

Cullinan, E. R. and MacDougali, I. P. (1957). Lancet, 1, 487.

Gelber, I., Hawthorne, H. R. and Gelb, A. (1955). Gastroenterology, 28, 836 .

Hagan, W. H. and Hagan, H. (1957). Sth med. J. (Bgham, Ala.),

Helmholz, H. F. (1923). Amer. J. Dis. Child., 26, 418.

Holowach, J. and Thurston, D. L. (1956). J. Pediat., 48, 279.

Hurt, L. E. (1954). Ann. Surg., 139, 838.

Jackman, R. J., Bargen, J. A. and Helmholz, H. F. (1940). Amer. J. Dis. Child., 59, 459

Kiefer, E. D., Eytinge, E. J. and Johnson, A. C. (1951). Gastroenterology, 19, 51 .

Lagercrantz, R. (1955). Acta paediat. (Uppsala), 44, 302.

Lyons, A. S. (1956). Pediat. Clin. N. Amer., Feb. 1956, p. 153. and Garlock, J. H. (1951). Gastroenterology, 18, 170.

MacDougall, I. P. M. (1954). Brit. med. J., 1, 852

Meeker, I. A. and Goff, P. (1956). West. J. Surg., 64, 545.

Schlesinger, B. and Platt, J. (1958). Proc. roy. Soc. Med., 51, 733.

Sloan, W. P., Bargen, J. A. and Gage, R. P. (1950). Gastroenterology, 16,25 .

Sydenham, T. (1848). The Works of Thomas Sydenham, Vol. 1, p. 166. Sydenham Society, London.

Thorlakson, R. H. (1956). Surg. Gynec. Obstet., 103, 41.

Tidrick, R. T. and Hickey, R. C. (1956). J. Iowa St. med. Soc., 46, 485 .

Weckesser, E. C. and Chinn, A. B. (1953). J. Amer. med. Ass., 152, 905 . Wilcox, H. R. and Beattie, J. L. (1956). Amer. J. clin. Path., 26, 